\title{
Chapter 12. Austronesian Societies and Their Transformations
}

\author{
James J. Fox
}

This paper examines the common Austronesian reliance on similar idioms and metaphors to define ideas of origins and on the use of narratives for the construction of a shared past. Thus common origin - not just "descent" — becomes a prime marker of identity. Among Austronesians, the sharing of a journey may be part of this reckoning of social ancestry. Within this cultural framework, the paper considers two formal systems of differentiation: the one, a system of lateral expansion; the other, a system of apical demotion with concomitant predatory expulsion. Each system relies on a differently structured narrative of the past on which to base its construction of origins.

\section{Introduction}

Austronesian societies offer a spectacle of diversity. There are at least eight hundred contemporary Austronesian societies, each of which can be considered to possess a distinct, if not distinctive, social organization; and, if one were to add to this number those Austronesian societies on whose early social formations we possess reasonable historical information, this diversity is further increased.

Such social diversity ranges from that of simple hunter-horticulturalists such as the Buid of Mindoro, the Ilongot of Luzon, the Penan of Borneo, the Sakkudei of the Mentawai islands, or the Huaulu of Ceram to the elaborate command states of the Merina of Madagascar, the Javanese of the Majapahit and Mataram periods, or the complex island kingdoms of Tonga, Tahiti, and Hawaii; from migratory sea populations such as the Sama-Bajau, or the trading societies of the Moluccas and of the Massim with their inter-island networks of ritualized exchange valuables to the predatory seafaring societies of the Malays, Bugis, Makassarese and Tausug.

A diversity of island environments has called forth adaptations that have also spawned great social variety: coastal sago palm exploiters such as the Waropen; elusive jungle nomads like the Kubu of Sumatra; tiny fishing populations on atolls in the Pacific; riverine peoples such as the Dayak, Kenyah or Kayan of Borneo; the maize-cultivating mountain populations like the Atoni Meto of Timor, for whom a view of the sea was once considered distressing; dryland palm tappers such as the Rotinese and Savunese in eastern Indonesia; cattle herding peoples such as the Bara of south central Madagascar; yam, taro, and sweet-potato gardeners of the Melanesian islands, some of whom, like those on Goodenough Island or the Trobriands, flaunt their harvests in feasting for 
recognition; expansive swidden-rice cultivators like the Iban of Borneo; or settled rice farmers like the Ifugao of Luzon with centuries of collective investment in elaborate terraces.

Religion has also contributed to this diversity. Islam has influenced the societies of western Austronesia as has Hinduism and Buddhism; and Christianity has had its influence through the whole of the Austronesian world from Madagascar to Hawaii and from the Philippines to Timor. There are also scattered Austronesian populations who have taken on no world religion — or, have even formally rejected such possibilities. Such populations are often identified, by the nineteenth century categorical designation, as "animists". These Austronesians share with most other Austronesian peoples, though perhaps in more explicit fashion, a general belief in life and in the interrelationship of different forms of life. In the Austronesian world, the mosque, the temple, the church, or simply a tree set among a pile of rocks is part of the diversity of social life.

Confronted with this spectacle of diversity, the question is whether there exists among these many societies social features that may be identifiable as characteristically Austronesian. Certainly in answer to this question, anthropologists investigating societies in different regions of the Austronesian world have fashioned a formidable array of technical designations. We have cognatic and non-cognatic societies; lineal and nonlineal, patrilineal, matrilineal, bilineal, quasi-unilineal, ambilineal, and double unilineal societies; societies with kindreds, with ramages, with bilateral descent groups, with optative descent groups, with status lineages, with circulating connubium, generalized exchange, symmetric and asymmetric marriage. Sorting one's way through the formal technicalities of all of this apparatus is almost as daunting as investigating the original diversity of societies which this apparatus was intended to illuminate.

A singular difficulty with the current sociological apparatus available for the study of Austronesian societies is that it has been shaped within specific regions. Reflecting the particularities of these regions, the terminology of one area does not travel well - and certainly not as well as the Austronesians themselves from one region to another. Instead of encompassing the full sweep of Austronesian diversity, our present terminology is partisan to particular variants of the whole. Another less apparent difficulty is that this sociological apparatus makes implicit assumptions about the nature of social life which the Austronesians themselves do not seem to share. Austronesian ideas about persons, about the union of persons, about social derivation and identity, about sociability itself, such ideas are not - or, were not - those of nineteenth century Europe from which our sociological traditions derive.

In the study of Austronesian societies and their transformations, it is best to reexamine our own premises and to focus on a few basic features of a general 
nature. At the same time, it is essential to attend closely to the concepts of the Austronesians themselves expressed in idioms and metaphors of a common linguistic and cultural heritage. In the process, it is inevitable that we abandon some of our previous preoccupations ${ }^{1}$ and with them jettison the conceptual encumbrances that have limited a comparative understanding of the Austronesians.

This effort may give us a fresh start on a new voyage of investigation. My purpose in this paper therefore will be to examine a few key ideas that recur throughout the Austronesian-speaking world and to consider their implications in the transformation of Austronesian societies. In this paper, I will look first at the concept of "origin" among the Austronesians and then, from this vantage point, at specific formal structures of social differentiation. I will illustrate my discussion by selective citations of particular well-known Austronesian ethnographies. My intention is not to create a composite picture of Austronesian society but just the opposite - to identify differences that derive from shared similarities.

\section{The Concept of Origin}

Our own ideas of origin — either the Judeao-Christian-Muslim or the evolutionary view of human derivation - ill prepare us to appreciate Austronesian ideas of origin or to take seriously the implications of these ideas. Our ideas look to a unitary, if not unified, conception of origin whereas the Austronesians tolerate - or, rather relish - the notion of multiple origins. Often this multiplicity derives from an initial unity that is shattered - the destruction of a cosmic tree, the internal rupture of a universal egg, or the separation of a primary couple - but once this unity is shattered, concern is with a multiplicity of entities. Although this general notion may be applied to all beings, I shall confine myself here to ideas of the origin of humankind and its implications for the structuring of society.

In some myths, a creator god attempts various experiments before achieving the appropriate creature. Usually this creature is an aristocratic form of human being - not the progenitor of all humankind. In other myths, a variety of humans derive from the destruction of different parts of a cosmic tree; in still others, this variety comes from the fertile union of different sorts of beings. In most Austronesian societies, however, a multiplicity of origins is assumed and groups as well as individuals are allowed to trace their origins as is deemed appropriate for social differentiation. The sharing of origins is socially defined and thus always circumscribed. Thus in a now classic ethnography, Michael Young reports that the eight clans of the Kalauna of Goodenough Island emerged from the earth in a specific order "bringing with them the customs and competences by which [they] ...are still identified" (1971:29). The same description would hold for the hundreds of name-clans of the Atoni Meto of 
Timor, most of whom trace their separate origins to some emergence site marked by a rock and tree.

Under the influence of Islam or Christianity, some unifying of human origin accounts has occurred. The rulers of Java trace a double origin relying on genealogies of the right and left, one of which derives from the gods and heroes of Java, the other from the prophet and saints of Islam. Similarly the aristocracy of some of the domains of Roti have included Biblical figures in their own royal genealogies but such genealogies do not embrace all members of their own domain; they would deny a common origin with all of their commoner class. The introduction of new sacred versions of origin have enhanced rather than obliterated the idea of multiple origins.

The notion of multiple origins is a prime means of social differentiation. Such a notion may operate at many levels within a society. For my purposes here, I want to concentrate on the implications of this notion for the structuring of society, focusing on selected examples. I use the phrase "origin structure" as a general designation for the diversity of social formation by which Austronesians explain and order their derivation.

\section{Stranger Kings, Muslim Saints and Brahmana Priests}

Marshall Sahlins, in a well-known essay on "The Stranger-King", has called attention to the origin of the Noikoro chiefs of Fiji who trace their beginnings from a handsome stranger who is carried to the shore of Viti Levu by a shark, wanders into the interior of the island, is taken in by a local chief whose daughter he marries and becomes the founder of the ruling clan known as "The Sharks". Thus the ruler has a different origin from the rest of the population; he is a stranger, a guest, a person of the sea as opposed to the people of the land. In form, this is a classic origin narrative that is repeated in different guises throughout the Austronesian world. In Timor, the ancestor of the ruling line of Sonbai is discovered in mysterious circumstances as a resplendent youth who is taken in by the local population and elevated to ruler. The Sonbai ruler was treated like the Fijian ruler. To quote Sahlins: "he is ... immobilized: he "just sits,' Fijians say, i.e., in the house as a woman — 'and things are brought to him"' (Sahlins 1985:91).

Another variant of this narrative can be seen in the origin of the ruling line of Termanu on the island of Roti. Here the ancestor of the ruling clan arrives from the sea and in a series of contests outwits the ancestor of the land, thereby gaining rule but without ritual authority over the earth. Thus the ruler shares a different origin from the head of the earth and this dichotomy forms the basis of the domain.

Structurally similar variants of this narrative are cited as the foundation of many of the ruling lines of the coastal states of Western Indonesia. To cite but 
one example, the founder of the once powerful line of the Muslim ruler-saints of Giri on the north coast of Java was washed ashore in a box at Gresik and raised by a pious widow. This figure, known originally as Jaka Samodra, "Sea Youth", became the first Sunan Giri, one of the most important purveyors of Islam on Java (Fox 1991:24-28).

Another variant of this narrative serves as one of the principal legendary charters for the structure of Bali. This legend begins with a victory by the Javanese Hindu kingdom of Majapahit in Bali and the despatch of a noble entourage led by a Brahmana priest named as Ida Dalam Ketut Kresna Kepakisan to bring civilization to the island. From this priest and his entourage come the ruling Triwangsa who continue even after the fall of Majapahit to provide the knowledge of the Hindu rituals and of statecraft that transforms the Bali Aga populations of the island. Only a minority on Bali, however, are twiceborn; the charter of their origin links spiritual derivation with a historical locality, physical conquest with civilizing status and distinguishes them from the majority of the population. This enduring charter is predicated on multiple origins and the perpetuation of different statuses. Instead of being contested, it is further embellished by other charters that also claim separate origins for particular social groups (Fox in press).

A diversity of origins within the same society creates a diversity of possibilities. In many Austronesian societies, origins are conceptualized as a form of growth: derivation from a "source", "root", "base", or "trunk". In this structure, which may be graphically described as a tree, vine or climbing plant, growth is either upward or outward toward a "tip" or apical point. The Rotinese use this metaphor to describe their maternal origins as well as the structure of their clans; other populations in eastern Indonesia, such as the Weyewa of Sumba, the Mambai of East Timor or the Atoni of West Timor use a similar metaphor to describe "origin structures" of varying sorts (Fox 1971, 1980, 1988a; Kuipers 1985; McWilliam 1990; Traube 1989). The central Polynesians use the same metaphor to trace origins among different island populations; the Satawal of Micronesia to identify the matrilineal source clans on their island of origin (Siikala in press; Sudo in press).

Where this metaphor is used to describe specific groups, it would be more appropriate to refer to these groups as "ascent groups" rather than "descent groups" - an observation made some years ago by Hooper in his discussion of Tahitian social organization (1970). For these groups, social reckoning is from a base upwards, rather than from some apex downward (see Fox 1988a). Often in societies with such ascent structures, one group "grows" to prominence and it is around this group that other ascent groups cluster. Thus in Termanu on the island of Roti, one clan, Masa-Huk, of outside origin forms the base (huk) that 
gives rise to a complex set of multiple lineage branches (ndanak) in whose shadow other lesser clans are shaded.

Such "ascent groups", however, are only one form of origin structure among the Austronesians. Heavenly origins are also a common form of "outside origin". Groups claiming origins of this sort may more aptly be called "descent groups". The nobility in societies of southern Sulawesi - the Bugis, Makassarese and some Toraja - trace their origins to a class of heavenly beings known as the tomanurung, the "descenders" who contributed the white blood that distinguishes nobles from commoners. Like the rulers of Fiji, the lords of Timor, or the Triwangsa of Bali, the nobles of southern Sulawesi trace separate origins distinct from the rest of the population over whom they hold authority.

\section{Origin, Narrative and Journey}

Michael Young, in his account of Goodenough Island (Young 1971), describes the origin structures of the Kalauna: the separate emergence of a succession of eight clans; the establishment of pre-eminence by the second of these clans based on a knowledge of the generative rituals for the main foodstuffs; the split within this clan; the sharing and assignment of tasks to the other clans; and, finally, the account of the various events that led to the scattering of some clans and the "journey" or migration of the others from their place of origin to the present settlement, most of which, as Young explains, is told by the pre-eminent clan itself.

This account begins with multiple origins, assigns an order of precedence among the clans and pre-eminence to one clan whose internal divisions are thereafter significant. In Young's phrase, it designates the "competences" of the clans and recounts the vicissitudes of their journey through various places to the present. Each clan recounts its separate origin narrative; only the account of the pre-eminent clan contains the information that links the separate accounts to one another and explains the origins of the principal exchange institutions of the society. Finally, to the public account of each narrative is attached an esoteric component that reveals to its members alone the magical formulae of the group. These accounts, which are of evident importance to the Kalauna, are - even in their ambiguity — paradigmatic of the sort of narratives that establish an Austronesian "origin structure".

Compare these narratives of origin with those of several other societies from different parts of the Austronesian world. In a recent ethnography, E. Douglas Lewis (1988) presents the narratives of origin of the Ata Tana 'Ai of east central Flores. These narratives are immensely complex and detailed and Lewis devotes twenty-five pages of his ethnography to outline their basic structure. They form the foundation of the domain of Wai Brama and must be recounted in ritual language at the principal ceremonial celebration of the domain. The rituals speak 
of a community of "ten clans plus", although in fact there are twenty-five separate clans resident within the domain.

Each clan recounts its separate origin and its particular journey into Tana 'Ai. One clan — in Lewis' words, "the source clan" — is pre-eminent. This clan possesses the narrative that integrates the other clans to it. As among the Kalauna, this clan's "history" is especially complex because its own internal division is of great significance. For the source clan of Tana 'Ai, this internal division is an ancestral elder/younger bifurcation represented by critical differences encountered in hunting together. On arriving in Tana 'Ai, the elder of the brothers assigns precedence to the ancestors of the other clans as they, in turn, arrive; the younger brother marries with these ancestors and shares out ceremonial goods and ritual duties. An ambiguous third ancestor who accompanies the two brothers at the outset takes a divergent journey and finally arrives in Tana 'Ai to become the founder of the lowest clans of the domain.

To quote Lewis: “The people of each Tana 'Ai clan conceive of themselves as making up a group by virtue of descent from ancestors named in the histories, who were the first people of the clan to arrive in the various localities occupied by the clan ... Furthermore the Ata Tana 'Ai say that each of their clans originated from a different place. Thus the histories serve to identify each clan in terms of its origins and to distinguish each clan from every other clan" (Lewis 1988:61).

Like the narratives of the Kalauna but in a more elaborate fashion, the histories of Tana 'Ai serve as the charter for the society's origin structures. In the case of the Kalauna, these structures encompass a single settlement; for the Ata Tana 'Ai, they encompass a region that forms a single ritual domain. Instances of similar narrative accounts of origins could be cited from the ethnographies of the Timor area (Renard-Clamagirand 1982; McWilliam 1990) or from Roti where such narratives establish a class system with all of the prerogatives of rule and authority. It is more instructive to consider another example, typical of its kind, where similar narratives are told at a more individual level.

The case of the Ilongot, a small-scale hunter-horticultural population in Luzon, may be taken for present purposes to represent a class of Austronesian societies often distinguished by their lack of clans or lineages from societies like the Kalauna or Ata Tana 'Ai. The household group is important in all these societies but a further scaffolding of relations is seemingly less elaborate among the Ilongot. The idiom of relationship, however, is articulated in a similar fashion.

Among the Ilongot, each household is regarded as "one trunk" (tan tengeng). These "trunks" form local clusters generally denoted by the names of rivers or other prominent features of their environment. The boundaries of these settlements and the affiliation of households within them is flexibly interpreted. But in each settlement, according to Michelle Rosaldo, 
there is at least a core group of closely related families who are apt to share a history of common residence, having lived in close proximity over years of intermittent movement in search of fertile lands, abundant forests, or freedom from lowland law. It is this history of coordinated moves, through times of inward-turning "concentration" and then "dispersal" toward the lowland margins of Ilongot lands, that lends a settlement its viability as an ill-defined yet generally recognized and cooperating social group (M. Rosaldo 1980:5).

Like the Kalauna and Ata Tana 'Ai, Ilongot also possess origin narratives that relate journeys of the past. Although they focus mainly on the recounted memories of their oldest living members, these narratives nevertheless articulate two distinct levels of origin. Again to quote Michelle Rosaldo:

A history of related moves, interpreted in an idiom of bilateral kinship and reinforced by bonds of marriage, permit most members of a settlement to construe themselves as kin, who (as Ilongots express it) share a "body" (betrang) ... What continues over time is not a stable group but a tradition of relation (M. Rosaldo 1980:9).

Here kinship is constituted by a shared journey which includes hunting together. A tradition of such shared relationship points to still earlier origins.

Those people who have shared in hunts, along with kin in other settlements with whom they have been wont to live at times of "concentration", will tend to see themselves as members of a single bertan ... Bertan, unlike settlements, are seen by Ilongot as timeless and discrete collections of related persons who share an origin from unknown common ancestors who once lived together "downstream", "in the lowlands", "on an island", "near a mountain" - in short, in some environment from which the bertan takes its name (M. Rosaldo 1980:9).

Ilongot society is composed of at least thirteen such discrete, named, and loosely localized groups. Seen from a perspective of origin structures, there is little formal difference between the Ilongot, the Kalauna or the Ata Tana 'Ai except in the way in which each of these societies reckons its path of origin through the father in the case of the Kalauna, the mother in the case of Ata Tana 'Ai or through either parent in the case of the Ilongot. In all of these societies, the sharing of a journey is part of the reckoning of social ancestry. This reckoning is enhanced by the recurrent linguistic use of terms for "path" as a common Austronesian metaphor for social relationships.

In comparing these societies, one crucial difference needs to be pointed out in the case of the Ilongot. All the bertan of the Ilongot recount their own separate 
narrative of origin; no member of a bertan recites a narrative that links the bertan to each other as a group.

\section{Transformations of Austronesian Societies}

The three societies I have focused on were chosen purposely. In historical linguistic terms, which are relevant to this discussion, each of these societies belongs to a different Malayo-Polynesian subgroup: the Ilongot belong to the Western; the Ata Tana 'Ai to the Central; and the Kalauna to the Eastern. Together they cover a wide dispersal of Austronesian-speaking peoples. However, in the anthropological literature that has made descent and marriage the principal if not exclusive - criteria for defining and typifying Austronesian societies, such societies as these would rarely be considered together except possibly as contrastive types. ${ }^{2}$ My purpose in considering these three societies was to show their similarities to one another, particularly in their concern with origins as a prime marker of social identity. In doing this, I have simply attempted to take seriously precisely those features of identity that the members of these societies appear to regard as fundamentally important.

Having set the stage for an alternative understanding of Austronesian societies through a consideration of their origin structures, I now wish to extend my initial observations in a more speculative fashion. If one were to adopt a bird's eye (or perhaps better, a "satellite") view of the Austronesian societies from Madagascar to Hawaii, one might venture a few generalizations based on our current knowledge of these societies. The first of these is that the Austronesians show a range of ways in which they reckon their social origins: from fully bilateral reckoning to strict lineal reckoning. The majority of Austronesian societies, when examined closely, are neither fully bilateral nor strictly lineal. This large middle range of Austronesian societies that is neither exclusively one nor the other is, of course, what is interesting to the analyst of social organization. But for the purposes of analysis, it is better to examine the two extremes of the continuum. If, as a first approximation, one were to ask not just which societies are the most bilateral in their modes of social reckoning but where these societies are located, a crude pattern appears to emerge. These societies are found on the relatively large islands of the Austronesian world, areas of potential expansion, where land and other resources are (or, in recent historical times, were once) readily available. Thus bilateral societies are most common in the main Philippine islands but particularly in northern Luzon, Mindoro and much of Mindanao; in Borneo; large areas of Madagascar, and in Java; but bilateral reckoning is also characteristic of the early Maori of New Zealand and of historical Hawaiians. ${ }^{3}$ The principal mode of social differentiation in these societies is relative age (i.e. elder/younger) which may, in certain contexts, provide the means of creating an extended order of precedence (as, for example, amongst the Maori) but more generally offers an opportune line of fission, whereby the younger — or in a 
few cases, the elder - sibling simply moves away to found a new settlement. The founder of this new settlement thus becomes the point for a new system of local precedence (Bellwood in press). I would describe all of these systems as systems of lateral expansion.

In contrast to these societies are those that endeavour to restrict social reckoning in an ever-more-exclusive mode. Again, if one looks to the distribution of these societies, they are to be found on smaller islands, but not on islands too small to support such exclusivity, on the coastal margins of large islands where they are (or were) concerned with trading and raiding, and also among specific notable status groups in the very midst of societies with bilateral reckoning. Status is a preoccupation in these societies and it is reckoned in subtle and complex ways. Such societies are centred on a single source. Elaborate narratives of origin - and with them, exclusive genealogies - to this source are seen as a prerogative of high status. Such narratives are exclusively preserved and jealously guarded. The degree to which such exclusivity is achieved may vary as do the means to achieve precedence in such societies.

What is striking is that throughout the Austronesian world the same formal structure has been devised for achieving this exclusivity. I refer to this formal structure as a system of apical demotion. ${ }^{4}$ In such a system, only one line retains status; and within that line, in each generation, ultimately one individual. All other individuals are automatically demoted and thus lose status relative to a single apical point. Unless they can manage to reunite their line with that of the highest status line, they continue to decrease in status. Such a society has a single source of precedence with restricted modes of reckoning relationships to this source.

Examples of societies that have developed systems of apical demotion are numerous but these systems, by their exclusivity, generally do not apply to the whole of these societies. Apical demotion is a dynastic device of an elite to distinguish itself from the majority of its own society. This form of precedence emerges within particular societies and invariably leads to an internal division, whereby one segment of society traces exclusive origins in marked contrast to a more reflexible reckoning of origins by the rest of the population.

Such systems of apical demotion are generally to be found in societies with royalty - rulers, kings, rajas, sultans and sacred chiefs - though not all such societies rely only upon apical demotion. Examples of such systems are those of the Merina aristocracy, the ruling classes of the Malay states as well as those of the former Bugis and Makassarese, or of the nobility of Mataram on Java and of the high Balinese who claim to come from the kingdom of Majapahit. In eastern Indonesia, the ruling clans in many of the states and domains of the region in eastern Sumba or in central Roti, for example - are predicated on systems 
of apical demotion. In the Pacific, the classic systems of this sort are those ruling elite of Tonga, Samoa, Tahiti and Hawaii.

As a first step, it is useful to note some of the common features of systems of apical demotion wherever they occur in the Austronesian world. With this perspective, it is possible to recognize formal resemblances between Bali and Tonga or the Merina kingdom and the Malay states. It is, however, the differences among these systems that are of equal interest. Thus within a formal system, it becomes possible to delineate specific structural differences. In systems of apical demotion, it is not the way that status is automatically diminished that is significant, but rather the variety of ways by which status, in different systems, is maintained and promoted.

Thus generally within the western subgroup of Malayo-Polynesians, a greater relative stress is placed on the husband/wife couple as a focus of status determination. Genealogies that record high status often preserve the names of marriage partners (see Bulbeck, in press, for a particularly lucid examination of the Makassarese system of apical demotion based on substantial written records of married couples). Status derives from both sides of the marriage and involves a careful balance. Further elements may add weight to this balance. Among the Merina, the first-born is a social category of particular importance. Hence the marriage of a first-born man of high rank with a first-born woman of equally high rank was the ideal device for attaining apical distinction. By contrast, in the central-eastern subgroups of Malayo-Polynesians, greater stress is focused on the brother/sister pair. A cultural ideal, muted among the Western Malayo-Polynesians, is that the brother/sister pair (or the lines of sibling differentiation that they represent) should be reunited in their offspring. Among the Central Malayo-Polynesians, the brother in this pair is accorded positive status with the result that, in structural terms, the mother's brother's line retains and confers status. Marriages tend to return to this line to maintain status. Further to the east, especially in Polynesia, greater weighting is given to the sister in this pair with the result that relations to the father's sister's line are crucial to status reckoning. Tonga represents an excellent example of this Austronesian transformation.

Another characteristic feature of systems of apical demotion relates not to the achievement of status but to what occurs when the achievement of status is blocked. Systems of apical demotion often function as systems of predatory expulsion. They regularly expel frustrated figures of high status who, by the authority of their status, can gather around themselves followers who will join them in leaving the old system and establishing a new status system elsewhere. The history of the Austronesians, especially as this history is told in elaborate oral narratives or early written chronicles, is replete with instances of predatory expulsion. The point to be made, however, is that this form of expansion is a 
result of "crowding" in the system. Without "crowding" — with few restrictions on resources of land and water - systems of apical demotion do not arise and expansion is more likely to occur by lateral "hiving off" of social groups of equal status.

\section{Conclusions}

In this paper, I have described a contrast between two formal systems that are to be found among the Austronesians: the one, a system of lateral expansion and the other, a system of apical demotion with concomitant predatory expulsion. As contrastive forms, these formal systems focus our attention and allow us to delineate a variety of intermediate structural forms. I would like to go a step further and link these formal systems to the more general discussion of "origin structures" with which I began this paper.

I would argue that in systems of lateral expansion, narratives of origin focus on place. In such systems, there occurs what Renato Rosaldo has called, in regard to the Ilongot, a "spatialization of time": "The cultural conception of shifting directions as one walks along a path is at once a pattern, reflecting past experiences, and a charter, guiding future projects" (R. Rosaldo 1980:59). An appropriate comparison here would be with the Atoni Meto whose history in the past two hundred years has been characterized by rapid lateral expansion that has left a complex network of chantlines outward from central west Timor. Atoni name groups (kanaf) trace their origins as the journey of a single name a single entity or collective ego - who wanders through a landscape of places. Atoni history is "the path and the road" and those who recite it personalize this collective history as "my path and my road" (Fox 1988a:10-15).

I would extend this argument by noting that systems of apical demotion invariably focus on persons rather than places. Genealogical reckoning becomes crucial to these systems. Origin narratives - many of which may begin with a recitation of places - come to focus on relationships among persons, on succession and the transmission of status. From this perspective, we can begin also to note, in the narration of origins, the occurrence of a "transition to genealogy" or its reverse in some instances.

If we consider these two contrasting formal systems as modes of expansion under particular conditions and in specific environments, we can see that both have been used widely and effectively. It becomes less important to designate one as the proto-system and the other as derivative than it is to recognize both as effective means by which populations of Austronesians have spread during their long history of expansion. 


\section{References}

Bellwood, P.

In press Hierarchy, founder ideology and Austronesian expansion. In J.J. Fox and C. Sather (eds) Origin, ancestry and alliance. Proceedings of the comparative Austronesian conference on hierarchy, ancestry, and alliance.

Bulbeck, F.D.

In press The Makassar State of Gowa. In J.J. Fox and C. Sather (eds) Origin, ancestry and alliance. Proceedings of the comparative Austronesian conference on hierarchy, ancestry, and alliance.

Dumont, L.

1967 Homo hierarchicus. Paris: Gallimard.

1977 Homo aequalis, I. Paris: Gallimard.

Fox, J.J.

1971 Sister's child as plant: metaphors in an idiom of consanguinity. In R.

Needham (ed.) Rethinking kinship and marriage, pp.219-252. London:

Tavistock.

1980 Models and metaphors: comparative research in eastern Indonesia. In J.J. Fox (ed.) The flow of life, pp.327-333. Cambridge: Harvard University Press.

1988a Origin, descent and precedence in the study of Austronesian societies. Public Lecture in connection with De Wisseleerstoel Indonesische Studien, 17 March 1988. Leiden University.

1988b Possible models of early Austronesian social organization. Asian Perspectives 26(1):35-43.

1991 Ziarah visits to the tombs of the Wali, the founders of Islam on Java. In M.C. Ricklefs (ed.) Islam in the Indonesian social context, pp.19-38. Centre for Southeast Asian Studies. Clayton (Vic.): Monash University.

In press Installing the 'outsider' inside: an exploration of an Austronesian culture theme and its social significance. Proceedings of The First International Conference on Austronesian Cultural Studies, Universitas Udayana, Bali.

Geertz, Clifford

1980 Negara: the theatre state in nineteenth century Bali. Princeton: Princeton University Press.

Geertz, Hildred and Clifford Geertz

1975 Kinship in Bali. Chicago: University of Chicago Press.

Gibson, T. 
1990 On predatory states in island Southeast Asia. Working Paper No. 2, Comparative Austronesian Project. Canberra: Department of Anthropology, Research School of Pacific Studies, The Australian National University.

Hooper, Antony

1970 'Blood' and 'belly': Tahitian concepts of kinship and descent. In Jean Pouillon et Pierre Maranda, Échanges et communications: mélanges offerts àClaude Lévi-Strauss àl'occasion de son 60 ème anniversaire, Tome I. The Hague and Paris: Mouton.

Kuipers, J.

1985 When the 'tip' forgets the 'trunk': remembering and forgetting in Weyewa oral performance. Paper delivered at the Meetings of the American Anthropological Association, December 1985.

Lewis, E.D.

1988 People of the source. Verhandelingen van het Koninklijk Instituut voor Taal-, Land- en Volkenkunde 135. Dordrecht: Foris Publication.

McWilliam, A.

1990 Narrating the gate and the path: place and precedence in southwest Timor. Unpublished PhD thesis. Canberra: The Australian National University.

Renard-Clamagirand, B.

1982 Marobo: Une société ema de Timor. Langues et Civilization de L'Asie du Sud-Est et du Monde Insulindien 12. Paris: Société d'Études Linguistiques et Anthropologiques de France.

Rosaldo, M.

1980 Knowledge and passion. Cambridge: Cambridge University Press.

Rosaldo, R.

1980 Ilongot headhunting. Stanford: Stanford University Press.

Sahlins, M.

1985 The stranger king; or, Dumézil among the Fijians. In Islands of History, pp.73-103. Chicago: University of Chicago Press.

Siikala, Jukka

In press The elder and the younger - foreign and autochthonous origin and hierarchy in the Cook Islands. In J.J. Fox and C. Sather (eds) Origin, ancestry and alliance. Proceedings of the comparative Austronesian conference on hierarchy, ancestry, and alliance. 
Sudo, Ken-ichi

In press Hierarchy and routes of migration: chieftainship and ranking in the Central Caroline Islands. In J.J. Fox and C. Sather (eds) Origin, ancestry and alliance. Proceedings of the comparative Austronesian conference on hierarchy, ancestry, and alliance.

Traube, E.G.

1989 Obligations to the source: complementarity and hierarchy in an eastern Indonesian society. In D. Maybury-Lewis and U. Almagor (eds) The attraction of opposites: thought and society in a dualistic mode, pp.321-344. Ann Arbor: University of Michigan Press.

\section{Young, M.W.}

\section{Fighting with food. Cambridge: Cambridge University Press.}

\section{Notes}

1 One of the chief preoccupations that I wish to set aside is the concern with a dichotomy between hierarchy and equality. Interest in this dichotomy in its most current form is associated with the work of Louis Dumont whose books, Homo hierarchicus (1967) and Homo aequalis, I (1977), have set the stage for present discussion. I would note, however, that concern with this dichotomy has a long history in Western thought and evidence from Austronesian societies has been taken up in European discussions of these issues from the time of early contact. This discussion has not, however, advanced the comparative understanding of the Austronesians, but has instead led to a pernicious dichotomization that has tended to sort Austronesian societies on one or another side of a great divide. As a result, comparisons, for example, between Iban and the Javanese, between the Buid and the Balinese, or the Ilongot and the Rotinese is hardly attempted. In a number of recent papers, I have used the concept of "precedence" not as a substitute for hierarchy, as some have interpreted it, but as an analytic category intended to crosscut the dichotomy between hierarchy and equality. It is my contention that all Austronesian societies in different and varying ways make use of precedence as a means of social and individual differentiation.

${ }^{2}$ Here one must be careful to distinguish societies that insist on exclusive social reckoning from satellite societies that attempt, with great effort, to retain social links to what they regard as more prestigious sources of origin.

3 At the very general level at which these observations are intended, it could be argued that there is effectively little difference between a bilateral system and a two-section (or two-line system) of kinship reckoning. I have elsewhere (Fox 1988b) pointed to the structural similarities between these two systems in Austronesian terminologies. Were one to accept these similarities, then much of Timor and Fiji could also be characterized as having systems of lateral expansion.

4 In the analysis of Balinese social organization, Clifford and Hildred Geertz aptly describe this system as that of "sinking status". See H. and C. Geertz (1975:128-131). Clifford Geertz, in particular, develops this idea in his study of the Balinese state in the nineteenth century (Geertz 1980). 